\title{
COMPARISON BETWEEN THE EFFECT OF THE COMMUNITY-BASED INTERACTIVE APPROACH AND THE INFLUENCE OF THE DISTRIBUTION OF BOOKLETS REGARDING THE SELF-MEDICATION KNOWLEDGE, ATTITUDE, AND BEHAVIOR OF STUDENTS
}

\author{
EKA KARTIKA UNTARI ${ }^{1}$, SUDIBYO SUPARDI ${ }^{2}$, RANI SAURIASARI ${ }^{3 *}$
}

${ }^{1}$ Department of Medicine, Pharmacy Study Program, University of Tanjungpura, Pontianak, Indonesia. ${ }^{2}$ Health Research and Development Agency, Indonesian Health Ministry, Indonesia. ${ }^{3}$ Department of Pharmacy, Faculty of Pharmacy, Universitas Indonesia, Depok, Indonesia.

Email: sauri94@gmail.com

Received: 21 April 2017, Revised and Accepted: 13 July 2017

ABSTRACT

Objective: This study was conducted to compare the effectiveness of booklet media and a community-based interactive approach (CBIA) on nonmedical science students. The study was conducted at the Departments of Pedagogy and Forestry at the University of Tanjungpura, Pontianak.

Methods: The study design was pre-experimental with a pre- and post-test of the respondents, who were divided into groups that either carried out the CBIA or were given a booklet. There were 78 respondents who participated in the study until its completion. Scores of knowledge, behaviors, and attitudes were measured with questionnaires, both before and 6 weeks after interventions with the CBIA and the booklet.

Results: The results demonstrate that both the CBIA and the booklet intervention significantly influence the level of knowledge, attitudes, and behaviors $(\mathrm{p}<0.05)$.

Conclusions: Although the distribution of the booklets was more effective than the CBIA method in improving the self-medication attitude of the students, both interventions were equally effective in improving the self-medication knowledge and behavior of the non-medical science students.

Keywords: Booklet, Community-based interactive approach, Knowledge, Self-medication, Student.

(c) 2017 The Authors. Published by Innovare Academic Sciences Pvt Ltd. This is an open access article under the CC BY license (http://creativecommons. org/licenses/by/4. 0/) DOI: http://dx.doi.org/10.22159/ajpcr.2017.v10s5.23106

\section{INTRODUCTION}

A society must play an active role to get healthy and be socially and economically productive. A society's effort to medicate itself is known as self-medication [1]. The practice of self-medication is commonly found in youngsters and students [2-5]. In the self-medication practices of students, there are inappropriate doses, dosage forms, frequency, duration of treatment, and poor knowledge of the students regarding self-medication; this is alongside the discovery of problems related to self-medication practice $[6,7]$.

Student groups can easily obtain information through media advertising exposure. Only a small proportion of students rely on journals and the internet to get the correct information about selfmedication [8]. Most of the information from electronic media contains complex and misleading information [9]. Limited knowledge of the culture of medicines and their use can cause medication errors in the implementation of self-medication $[1,9,10]$.

The Indonesian government introduced the active mother learning method program to empower the community in health education $[1,11]$. It has now turned into a community-based interactive approach (CBIA) involving not only housewives but also groups considered influential, such as students, are also involved in the health efforts as well $[11,12]$. A study comparing the effectiveness of the CBIA method with different respondents has not been found; at this point, students are expected to be the agents of change and spread self-medication information. The student population is considered as a group that can gain information the most easily and is expected to implement and spread information to their surroundings $[2,13,14]$. The purpose of this study is to compare the influence of the CBIA method by distributing booklets to improve self-medication knowledge, attitudes, and behavior.

\section{METHODS}

The study design was pre-experimental with a pre- and post-test group design; the respondents were divided into two groups: One carried out the CBIA, and the other was given the booklets. The study was undertaken in 2013, in Pontianak City, in the West Borneo province of Indonesia. The respondents were given intervention in the form of either the CBIA method or the booklets about selfmedication; this was done after the pre- and post-test were conducted 6 weeks after that. The data collected was obtained using questionnaires, which had previously been tested for validation and reliability.

The respondents were individuals who were willing to participate in the study and who provided informed consent. The minimum sample size for each intervention group was 26 respondents [15]. The sampling was done using a consecutive sampling method. The inclusion criteria for this study were (a) students of non-medical science departments of University of Tanjungpura, Pontianak, (b) domiciled in Pontianak, and (c) doing self-medication in the past month for at least one out of six specific complaints, namely, headaches, fever, common cold, cough, diarrhea, and gastritis. The exclusion criteria of this study were (a) having obtained education about self-medication, (b) having experienced severe or chronic diseases and is now hospitalized, (c) being in a post-surgery or surgery condition, and (d) having been disqualified from the study.

The analyses were done by univariate, bivariate, and multivariate analysis, using SPSS. The bivariate tests used were Wilcoxon, MannWhitney, and Chi-square. The multivariate test used in this study was logistic regression. The degree of significance used in the bivariate test was $\mathrm{p} \leq 0.05$, and in the multivariate test, it was $\mathrm{p} \leq 0.25$. 


\section{RESULTS}

Rationality of self-medication practice by students

Table 1 shows the distribution of the rationality of self-medication practice by students. Of the total respondents, $15.4 \%$ met all four criteria.

Influence of the CBIA and booklet intervention on the selfmedication knowledge, attitude, and behavior in students

The results of the Wilcoxon test (Table 2) show that the CBIA method and the distribution of the booklet both significantly increase the score of the self-medication knowledge, attitude, and behavior of the students. There are significant differences between the scores of knowledge, attitudes, and behaviors before and after the CBIA intervention ( $\mathrm{p} \leq 0.05)$.

Comparison between the effectiveness of the CBIA method and the distribution of the booklet in improving the self-medication knowledge, attitude, and behavior of students

The results previously obtained in the Mann-Whitney test, shown in Table 2, demonstrate that there are significant differences between the CBIA and the booklet intervention group in improving the self-medication attitude of students $(p=0.009>0.05)$. The booklet intervention significantly affects the attitude improvement. There is no significant difference in the scores of knowledge and behavior between the CBIA and the distribution of booklet interventions in improving the self-medication knowledge or the behavior of the students.

Influence of confounding factors on the improvement of self-medication knowledge, attitude, and the behavior of students The result of the Chi-square test (Table 3) shows that the variables of the status of semester and the relatives working as medical workers

Table 1: Distribution of self-medication rationality criteria of study samples

\begin{tabular}{ll}
\hline Self-medication rationality criteria & $\begin{array}{l}\text { Frequency } \\
\mathbf{n = 7 8} \text { (\%) }\end{array}$ \\
\hline Right medicine class & $19(24.4)$ \\
Right medicine & $58(74.4)$ \\
Right rule & $37(47.4)$ \\
Limited use of medicine (not more than 3 days) & $58(74.4)$ \\
Rational self-medication & $12(15.4)$ \\
\hline
\end{tabular}

potentially affect the dependent variable $(\mathrm{p} \leq 0.05)$ or potentially as confounding variables $(\mathrm{p} \leq 0.25)$. However, the results obtained in Table 3 show that the variables of status of semester and relatives working as medical workers do not affect the increase in knowledge, attitudes, and behaviors. The results of the multiple logistic regression test of the backward methods of the variables related to the improved self-medicine knowledge, attitude, and behavior of students are shown in Table 4 .

\section{DISCUSSION}

The rationality of the self-medication practice on students was still low, even the self-medication conducted by the medical students was wrong [7]. The rational use of medicines in self-medication was low due to the non-optimum knowledge of self-medication. Therefore, it requires effective and optimal education.

Both the CBIA method and the distribution of the booklet interventions manage to increase the scores of the self-medication knowledge, attitude, and behavior significantly. The previous study demonstrates that both the CBIA and the leaflets have been successful in improving knowledge, attitudes, and behaviors in self-medication practice [9]. The CBIA method can improve self-medication knowledge, attitudes, and behaviors due to its active or direct delivery of information from two sides between the respondents and the speakers. In comparison, the distribution of the booklet has a weakness, in that the information delivered is passive or it comes only from one source, the author.

The intervention significantly influences the attitude improvement. The intervention is the distribution of booklets, which gives significant influence - approximately 5 times higher than the CBIA method in improving the self-medication attitude of the students. Both interventions improved the knowledge and behavior significantly, as shown by the Wilcoxon test result, which was explained previously. The booklet used in this study is a visual aid that has many pages and broad content and is an information medium that is appropriate for the student respondents, making it more effective in improving selfmedication attitudes, as compared to the CBIA method.

\section{CONCLUSION}

Both the CBIA method and the distribution of booklets provide a significant influence on the improvement of self-medication knowledge,

Table 2: Comparison of scores of self-medication knowledge, attitude, and behavior before and after the CBIA and booklet intervention using Wilcoxon and Mann-Whitney test

\begin{tabular}{|c|c|c|c|c|c|c|c|}
\hline \multirow[t]{2}{*}{ Variables } & \multicolumn{3}{|l|}{ CBIA } & \multicolumn{3}{|l|}{ Booklet } & \multirow[t]{2}{*}{ pp Mann-Whitney } \\
\hline & Pre-test score & Post-test score & $\mathbf{p}$ & Score before & Score after & $\mathbf{p}$ & \\
\hline Knowledge & $11.70 \pm 1.288$ & $12.08 \pm 1.211$ & $<0.004^{*}$ & $10.71 \pm 1.792$ & $11.46 \pm 1.343$ & $<0.001^{*}$ & 0.368 \\
\hline Attitude & $14.54 \pm 1.592$ & $15.19 \pm 1.050$ & $<0.003^{*}$ & $14.10 \pm 2.577$ & $15.00 \pm 1.118$ & $<0.003^{*}$ & $0.009^{*}$ \\
\hline Behavior & $5.24 \pm 2.640$ & $6.16 \pm 2.021$ & $<0.003^{*}$ & $5.02 \pm 2.242$ & $5.80 \pm 1.939$ & $<0.001^{*}$ & 0.164 \\
\hline
\end{tabular}

Mann-Whitney tests; Remarks: *p: Significance $\leq 0.05$. CBIA: Community-based interactive approach

Table 3: Equality of possible confounding variables using the Chi-square test

\begin{tabular}{llc}
\hline Possible confounding variables & CBIA (\%) & Booklet (\%) \\
\hline Age & $17(55.3)$ & $21(44.7)$ \\
15-20 years & $20(50)$ & $20(50)$ \\
$>20$ years & $16(88.9)$ & $2(11.1)$ \\
Semester status & $1(25)$ & $3(75)$ \\
$2^{\text {nd }}$ semester & $5(13.5)$ & $32(86.5)$ \\
$4^{\text {th }}$ semester & $19(100)$ & 0.642 \\
$6^{\text {th }}$ semester & & 0.000 \\
$8^{\text {th }}$ semester & $28(46.7)$ & $32(53.3)$ \\
Relatives working as medical workers & $13(72.2)$ & $5(27.8)$ \\
Yes & & 0.050 \\
No & & \\
\hline
\end{tabular}

p: Significance $\leq 0.05$. CBIA: Community-based interactive approach 
Table 4: Results of the multiple logistic regression test of the backward methods of the variables related to the improved self-medicine knowledge, attitude, and behavior of students

\begin{tabular}{|c|c|c|c|c|}
\hline \multirow[t]{2}{*}{ Variables } & \multirow[t]{2}{*}{ Significant } & \multirow[t]{2}{*}{ OR } & \multicolumn{2}{|c|}{$\begin{array}{l}95 \% \text { CI for } \\
\operatorname{Exp}(B)\end{array}$} \\
\hline & & & Lower & Upper \\
\hline \multicolumn{5}{|l|}{ Knowledge } \\
\hline \multicolumn{5}{|l|}{ Step $3^{\mathrm{a}}$} \\
\hline Semester & 0.075 & & & \\
\hline Semester (1) & 0.129 & 2.889 & 0.735 & 11.360 \\
\hline Semester (2) & 0.424 & 0.370 & 0.032 & 4.231 \\
\hline Semester (3) & 0.377 & 0.602 & 0.195 & 1.855 \\
\hline \multicolumn{5}{|l|}{ Step $3^{a}$} \\
\hline \multicolumn{5}{|l|}{ Attitude } \\
\hline Intervention & 0.004 & 0.249 & 0.097 & 0.639 \\
\hline Constant & 0.006 & 7.749 & & \\
\hline \multicolumn{5}{|l|}{ Step $3^{\mathrm{a}}$} \\
\hline \multicolumn{5}{|l|}{ Behavior } \\
\hline Semester & 0.419 & & & \\
\hline Semester (1) & 0.642 & 0.725 & 0.187 & 2.809 \\
\hline Semester (2) & 0.999 & 0.000 & 0.000 & \\
\hline Semester (3) & 0.115 & 0.392 & 0.123 & 1.256 \\
\hline Constant & 0.117 & 2.167 & & \\
\hline
\end{tabular}

Odds ratio, $\mathrm{CI}$ : Confidence interval

attitudes, and behaviors. Although the booklet media is more effective at improving the attitude, the CBIA method and booklet media are equally effective in improving the self-medication knowledge and behavior of non-medical science students of this study.

\section{REFERENCES}

1. Departemen Kesehatan Republik Indonesia. Pedoman pengunaan obat bebas dan bebas terbatas. Direktorat Bina Farmasi Komunitas Dan Klinik: Ditjen Bina Kefarmasian Dan Alat Kesehatan. Jakarta:
Departemen Kesehatan RI; 2006.

2. Zafar SN, Syed R, Waqar S, Zubairi AJ, Vaqar T, Shaikh M, et al. Self-medication amongst university students of Karachi: Prevalence, knowledge and attitudes. J Pak Med Assoc 2008;58(4):214-7.

3. Dianawati O, Fasich F, Athijah U. The correlation between drug advertising and self medication behavior OF highschool student in Surabaya. Majalah Farmasi Komunitas 2008;6(1):10-6.

4. Hussain A, Khanum A. Self medication among university of Islamabad, Pakistan - A preeliminary study. South Med Rev 2008;1(1):14-6.

5. Shankar PR, Partha P, Shenoy N. Self-medication and nondoctor prescription practices in Pokhara valley, Western Nepal: A questionnaire-based study. BMC Fam Pract 2002;3:17.

6. James H, Handu SS, Khaja KA, Sequeira RP. Influence of medical training on self-medication by students. Int J Clin Pharmacol Ther 2008;46(1):23-9

7. Almasdy D, Sharrif A. Self-medication practice with nonprescription medication among university students : A review of the literature. Arch Pract Pharm 2011;2(3):95-100.

8. Sharma A, Madaan A, Nagappa AN. Medication storage and self medication practice among the youth in Karnataka region, India. Int J Pharm Sci Res 2012;3(8):2795-800.

9. Supardi S, Sampurno OD, Notosiswoyo M. Influence oral communication leaflet distribution to the appropriate self-medication activities. Buletin Penelitian Kesehatan 2002;30:128-38.

10. World Health Organization. The Role of Education in the Rational Use of Medicine. New Delhi: SEARO; 2006.

11. Kementerian Kesehatan Republik Indonesia. Modul Penggerakan Penggunaan Obat Rasional. Jakarta: Kementerian Kesehatan Republik Indonesia; 2002.

12. Suryawati S. CBIA: Improving the quality of self-medication through mothers' active learning. Essent Drugs Monit 2003;32:22-3.

13. Vijn TW, Fluit CR, Kremer JA, Beune T, Faber MJ, Wollersheim H. Involving medical students in providing patient education for real patients: A scoping review. J Gen Intern Med 2017;32(391):1-13.

14. Sawalha AF. A descriptive study of self-medication practices among Palestinian medical and nonmedical university students. Res Social Adm Pharm 2008;4(2):164-72.

15. Lwanga SK, Lemeshow S. Sample Size Determination in Health Studies. Geneva: World Health Organization; 1991. 